\title{
TOXIC MYOPATHIES
}

\section{Muscle biopsy features}

\author{
Rosana Herminia Scola, Eduardo Rafael Pereira, \\ Paulo José Lorenzoni, Lineu César Werneck
}

\begin{abstract}
Several drugs and toxic substances can cause muscular abnormalities and are frequent causes of acquired myopathies. We present a series of 32 patients, predominance of young adult patients, diagnosed with toxic myopathy. The most common substances inducing myopathy were corticosteroids (56.2\%) followed by the propoxyphene, neuroleptics, zidovudine and drug-induced hypokalemia. The investigation showed normal serum creatine kinase levels in $65.4 \%$, myopathic pattern of the needle electromyography in $40 \%$ and the more frequent histological diagnosis of the muscle biopsy was type 2 fiber atrophy $(59.3 \%)$. Clinical features, etiology, course of the disease, serum levels of muscular enzymes, electromyographic features and, especially, muscle biopsy features are discussed.
\end{abstract}

KEY WORDS: myopathy, drug, iatrogenic myopathy, toxic myopathy, muscle biopsy.

\section{Miopatia tóxica: biópsia muscular}

RESUMO - Diversos medicamentos e substâncias tóxicas podem causar alterações musculares e são causas freqüentes de miopatia adquirida. Apresentamos uma série de 32 pacientes, predomínio de pacientes adulto jovens, com miopatia tóxica. As substâncias mais relacionadas com a miopatia foram os corticosteróides $(56,2 \%)$ seguidos pelo propoxifeno, neurolépticos, zidovudina e drogas indutoras de hipocalemia. A investigação mostrou níveis normais de creatino quinase sérica em $65,4 \%$, eletromiografia de agulha com padrão miopático em $40 \%$ e o mais freqüente diagnóstico histológico da biópsia muscular foi atrofia de fibras do tipo 2 (59,3\%). As manifestações clínicas, etiologia, tempo de evolução, nível sérico das enzimas musculares, alterações da eletroneuromiografia e, especialmente, da biópsia muscular são discutidos.

PALAVRAS-CHAVE: miopatias, drogas, miopatia iatrogênica, miopatia tóxica, biópsia muscular.

A variety of drugs and toxic agents may produce muscular changes. Muscular aggression depends on individual susceptibility, dosage and affinity of the toxic agent for the muscle ${ }^{1-5}$. The dosage and the time of administration of the substance are fundamental to establish a possible causal relationship with the myopathy ${ }^{1-4}$.

The objective of this retrospective study was to analyze the etiology, evolution time, serum muscular enzymes variation, electromyographic features and muscular biopsy features in a series of patients suffering from of toxic myopathies (TM).

\section{METHOD}

A retrospective analysis of 4200 muscle biopsies performed at the Service of Neuromuscular Diseases, Division of Neurology, from January 1978 to July 2006 disclosed 32 patients with a diagnosis of TM. Relevant data, including clinical evaluation, age, sex, course of the disease, serum muscle enzymes levels, needle electromyography, and histological/histochemical aspects of the each muscle biopsy, were collected.

All patients had generalized or proximal weakness and a history of contact with either a drug or a toxic agent prior to the development of myopathy ${ }^{2}$. The time of progression of the disease was considered as the interval between the beginning of myopathic symptoms and the definitive diagnosis by muscle biopsy.

Abnormal serum levels of the muscle enzymes (creatine kinase and aldolase) were registered as a proportion reflecting their increase above normal limits. The needle electromyography (EMG) pattern was classified as normal, myopathic, denervation and mixed (myopathic with denervation findings) according to standard procedures ${ }^{6}$. Muscle biopsies were frozen in liquid nitrogen and cryostat sections were stained histologically, also according to standard procedures?.

All studies were done following informed consent.

Neuromuscular/Neurology Division, Internal Medicine Department, Hospital de Clínicas da Universidade Federal do Paraná (UFPR), Curitiba PR, Brasil.

Received 19 April 2006, received in final form 22 September 2006. Accepted 7 November 2006.

Dr. Lineu César Werneck - Serviço de Doenças Neuromusculares, Hospital de Clínicas da UFPR - Rua General Carneiro $181 / 3^{\circ}$ andar - 80060-900 Curitiba PR - Brasil. E-mail: werneck@hc.ufpr.br 
RESULTS

The sample consisted of 32 patients (19 female and 13 male), aged 10 to 72 years, showing a predominance of young adult patients in this series (19 patients with age between 15 and 40 years). The time of the progression of the disease varied between one day and 12 years, with a mean time of 29 months (Table 1).

The drugs that more frequently induced muscle changes in our group were corticosteroids in $56.2 \%$. In the other patients the myopathy was reported to propoxyphene intramuscular injections (6.2\%), haloperidol $(6.2 \%)$, hypokalemia induced by furosemide or propylthiouracil $(6.2 \%)$, zidovudine $(6.2 \%)$, epsilon aminocaproic acid (3.1\%), chloroquine (3.1\%), phenytoin (3.1\%), organophosphates (3.1\%), silicone mammary implants (3.1\%) and azathioprine (3.1\%).

Table 1. Description of the 32 cases.

\begin{tabular}{|c|c|c|c|c|c|c|c|c|}
\hline & $\begin{array}{l}\text { Age } \\
\text { (years) }\end{array}$ & Sex & $\begin{array}{l}\text { Evolution } \\
\text { time }\end{array}$ & Substances & Cause of the use & $\mathrm{CK} / \mathrm{AL}$ * & EMG & Muscle biopsy \\
\hline 1 & 24 & $\mathrm{~F}$ & 6 months & propoxifene IM & arthralgia & $\mathrm{N} / \mathrm{N}$ & $\mathrm{D}$ & Inflammatory myopathy \\
\hline 2 & 43 & M & 8 months & propoxifene IM & gout & $\mathrm{N} / \mathrm{N}$ & $M P+D$ & Inflammatory myopathy \\
\hline 3 & 56 & M & 24 months & prednisone $(C)$ & arthritis & $1 / N$ & MP & Type 2 fiber atrophy \\
\hline 4 & 39 & $\mathrm{~F}$ & 36 months & prednisone $(C)$ & myalgia & $\mathrm{N} / \mathrm{N}$ & MP & Normal \\
\hline 5 & 15 & M & 11 months & dexamethasone $(\mathrm{C})$ & pain & $1 / N$ & $\mathrm{MP}+\mathrm{D}$ & Type 2 fiber atrophy \\
\hline 6 & 64 & M & 12 months & prednisone $(C)$ & arthralgia & $N / N$ & $\mathrm{~N}$ & Type 2 fiber atrophy \\
\hline 7 & 29 & $\mathrm{~F}$ & 60 months & prednisone $(C)$ & myalgia & $\mathrm{N} / \mathrm{N}$ & ND & Type 2 fiber atrophy \\
\hline 8 & 35 & $\mathrm{~F}$ & 72 months & prednisone (C) & arthritis & $\mathrm{N} / \mathrm{N}$ & $\mathrm{MP}$ & Type 2 fiber atrophy \\
\hline 9 & 43 & $M$ & 36 months & prednisone $(C)$ & arthralgia & $\mathrm{N} / \mathrm{N}$ & MP & Type 2 fiber atrophy \\
\hline 10 & 24 & $\mathrm{~F}$ & 12 months & prednisone $(C)$ & arthritis & $\mathrm{N} / \mathrm{N}$ & MP & Type 2 fiber atrophy \\
\hline 11 & 34 & $\mathrm{~F}$ & 6 months & prednisone $(C)$ & lymphoma & ND/ 1,2 & ND & Type 2 fiber atrophy \\
\hline 12 & 30 & $M$ & 5 months & prednisone $(C)$ & aplastic anemia & $\mathrm{N} / \mathrm{N}$ & $\mathrm{N}$ & Type 2 fiber atrophy \\
\hline 13 & 44 & $\mathrm{~F}$ & 48 months & prednisone $(C)$ & depression & $\mathrm{N} / \mathrm{N}$ & $\mathrm{N}$ & Type 2 fiber atrophy \\
\hline 14 & 28 & $\mathrm{~F}$ & 60 months & prednisone $(C)$ & myalgia & ND / ND & MP & Type 2 fiber atrophy \\
\hline 15 & 43 & $\mathrm{~F}$ & 144 months & prednisone (C) & arthralgia & $\mathrm{N} / \mathrm{N}$ & $\mathrm{N}$ & Type 2 fiber atrophy \\
\hline 16 & 15 & $\mathrm{~F}$ & 1 month & EACA & thrombocytopenia & $100 / N D$ & ND & Acute myopathy \\
\hline 17 & 38 & $\mathrm{~F}$ & 96 months & chloroquine & malaria & $\mathrm{N} / \mathrm{N}$ & $\mathrm{N}$ & Mitochondrial myopathy \\
\hline 18 & 15 & M & 60 months & phenytoin & seizures & $\mathrm{ND} / \mathrm{ND}$ & ND & $\begin{array}{l}\text { Recent and chronic } \\
\text { denervation }\end{array}$ \\
\hline 19 & 46 & M & 6 months & organophosphate & poisoning & $1,1 / 1,1$ & $M P+D$ & Normal \\
\hline 20 & 30 & M & 1 month & haloperidol (NL) & psychosis & $24 / 7,4$ & $D$ & Normal \\
\hline 21 & 25 & $\mathrm{~F}$ & 6 months & haloperidol (NL) & psychosis & 15,3 / ND & ND & Type 2 fiber atrophy \\
\hline 22 & 28 & $M$ & 72 months & azathioprine & aplastic anemia & $\mathrm{ND} / \mathrm{ND}$ & MP & $\begin{array}{l}\text { Recent and chronic } \\
\text { denervation }\end{array}$ \\
\hline 23 & 41 & $M$ & 4 months & zidovudine & HIV & $60 / N D$ & $M P+D$ & Type 2 fiber atrophy \\
\hline 24 & 21 & $\mathrm{~F}$ & 1 day & furosemide $(H)$ & psychosis & $\mathrm{N} / \mathrm{ND}$ & $D$ & Active myophathy \\
\hline 25 & 55 & $\mathrm{~F}$ & 24 months & prednisone $(C)$ & MCTD & $120 / N D$ & $\mathrm{~N}$ & Type 2 fiber atrophy \\
\hline 26 & 10 & $\mathrm{~F}$ & 2 months & prednisone $(C)$ & arthralgia & $\mathrm{N} / \mathrm{ND}$ & $\mathrm{N}$ & Type 2 fiber atrophy \\
\hline 27 & 48 & $M$ & 8 months & dexamethasone $(\mathrm{C})$ & asthma & $6 / N D$ & MP & Type 2 fiber atrophy \\
\hline 28 & 37 & $\mathrm{~F}$ & 12 months & propylthiouracil (H) & Graves' disease & $\mathrm{N} / \mathrm{ND}$ & MP & $\begin{array}{l}\text { Myophosphorylase } \\
\text { deficiency }\end{array}$ \\
\hline 29 & 24 & $\mathrm{~F}$ & 7 days & prednisone (C) & aplastic anemia & $\mathrm{N} / \mathrm{ND}$ & MP & Type 2 fiber atrophy \\
\hline 30 & 47 & $\mathrm{~F}$ & 36 months & silicone & SMI & ND / ND & ND & Amyloid deposit \\
\hline 31 & 33 & $\mathrm{~F}$ & 36 months & prednisolone (C) & myalgia & $\mathrm{N} / \mathrm{N}$ & $M P+D$ & Type 2 fiber atrophy \\
\hline 32 & 72 & M & 24 months & zidovudine & HIV & ND / ND & ND & Mitochondrial myopathy \\
\hline
\end{tabular}

CK, creatine kinase; $\mathrm{AL}$, aldolase; *number of times (proportion) serum levels were increased above the normal limit; EMG, needle electromyography; F, female; M, male; IM, intramuscular injections; EACA, epsilon aminocaproic acid; (C), corticosteroid; (NL), neuroleptic; (H), hypokalemia; HIV, human immunodeficiency virus; MCTD, mixed connective tissue disease; SMI, silicone mammary implant; MP, myopathic pattern, D, denervation pattern; $\mathrm{N}_{\text {, }}$ normal; ND, not done. 
Table 2. Histological and histochemical abnormalities in muscle biopsy $(n=32)$.

\begin{tabular}{lc}
\hline Abnormalities & Cases \\
\hline Hematoxylin-eosin and modified Gomori-trichrome \\
Connective tissue proliferation & $3(9.3 \%)$ \\
Necrosis & $4(12.5 \%)$ \\
Phagocytosis & $4(12.5 \%)$ \\
Hypercontractile fibers & $1(3.1 \%)$ \\
Diffuse inflammatory infiltrate & $2(6.2 \%)$ \\
Variability of muscular fibers diameter & $32(100 \%)$ \\
Large agglomerations of atrophic fibers & $5(15.6 \%)$ \\
Atrophic rounded fibers dispersed & $2(6.2 \%)$ \\
Nuclear clumps & $3(9.3 \%)$ \\
Granular fibers (ragged reds) & $2(6.2 \%)$ \\
Vacuoles & $4(12.5 \%)$ \\
Amyloid deposis in interstitial tissue & $1(3.1 \%)$
\end{tabular}

\section{NADH - tetrazolium reductase}

Atrophic angulated fibers

Moth-eaten fibers

Focal increase NBT granules

Type grouping

\section{ATPase (pH 9.4, 4.6 and 4.3)}

Type 1 fiber atrophy

Type 2 fiber atrophy

Type 2 fiber predominance

$9(28.1 \%)$
$4(12.5 \%)$
$9(28.1 \%)$
$1(3.1 \%)$

$2(6.2 \%)$

$30(93.7 \%)$

$4(12.5 \%)$

\section{Nonspecific esterase}

Motor plate-increased size

Atrophic angulated fibers

Interstitial activity in mononuclears

\section{Acid phosphatase}

Focal increased into fibers

Interstitial isolated mononuclear cells

Phagocytes near or in necrotic fibers

\section{Alckaline phosphatase}

Interstitial increase

$6(18.7 \%)$

$6(18.7 \%)$

$1(3.1 \%)$

$6(18.7 \%)$

$2(6.2 \%)$

$1(3.1 \%)$

$6(18.7 \%)$

\section{Oil red 0}

Type 1 fiber increased

\section{Succinic dehydrogenase}

Sub-sarcolemal accumulation

Cytocrome C-oxidase

Subsarcolemal accumulation

\section{Siryus red}

Interstitial tissue increase

\section{Congo red}

Amyloid deposis in vessel and interstitial tissue

\section{Cresyl violet}

Metachromatic material

Myophosphorylase

Deficiency
Creatine kinase (CK) evaluation was performed in 26 patients and aldolase ( $A L)$ in 19 (Table 1). Serum CK levels varied from one up to 10 times normal levels in $15.4 \%, 11$ to 50 times in $7.6 \%$, were greater than 50 times in $11.6 \%$ and were normal in $65.4 \%$. Serum AL levels were increased in $10.5 \%$ and normal in $89.5 \%$.

The EMG pattern, observed in 25 patients, was myopathic in $40 \%$, neurogenic in $12 \%$, mixed in $20 \%$ and normal in the remaining $28 \%$ (Table 1). The EMG reveals myotonic discharges in two patients with myopathic pattern (case 22 and 29).

The commonest abnormalities found in muscle biopsies were: variability of the diameter of muscular fibers (100\%), type 2 fiber atrophy $(93.7 \%)$, atrophic angulated fibers in NADH (28.1\%), focal increase of NBT granules $(28.1 \%)$, increased size of motor plate in nonspecific esterase (18.7\%), focal increase into fiber in acid phosphatase (18.7\%) and alkaline phosphatase interstitial increase (18.7\%) (Table 2 / Fig 1). The histological diagnose were reported as: type 2 fiber atrophy (59.3\%), recent and chronic denervation $(6.25 \%)$, inflammatory myopathy $(6.25 \%)$, mitochondrial myopathy $(6.25 \%)$, active myopathy $(3.1 \%)$, acute myopathy $(3.1 \%)$, myophosphorylase deficiency (3.1\%) and amyloid deposit in interstitial tissue (3.1\%) (Fig 1). Some samples were diagnosed by histology as normal.

In the patients with muscular changes related to corticosteroids, the commonest findings were a mean time of progression of 33 months, normal levels of CK serum (75\%), normal levels of AL serum (92.3\%) and EMG with myopathic pattern (50\%).

\section{DISCUSSION}

Some times is difficult separate the muscle abnormalities due to the drugs used from the basic disease. In this study the agents more commonly related with myopathy were corticosteroids that can be associated either with acute or chronic myopathy; the latter was more common as had also been reported in other series $13,8,9$. This form of myopathy can occur in up to $60 \%$ or more of patients in chronic use of corticosteroids ${ }^{3}$. In the majority of these cases muscular biopsy reveals nonspecific type 2 fiber atrophy, according to our findings ${ }^{1,3,4}$. However, the pathogenesis behind such morphological abnormalities is not fully understood yet ${ }^{1,3,4}$.

The time of the progression of the disease demonstrated a predominance of chronic over acute cases in our series. Other drugs or toxics agents, as statins or alcohol, was not found in our series, possibly be- 


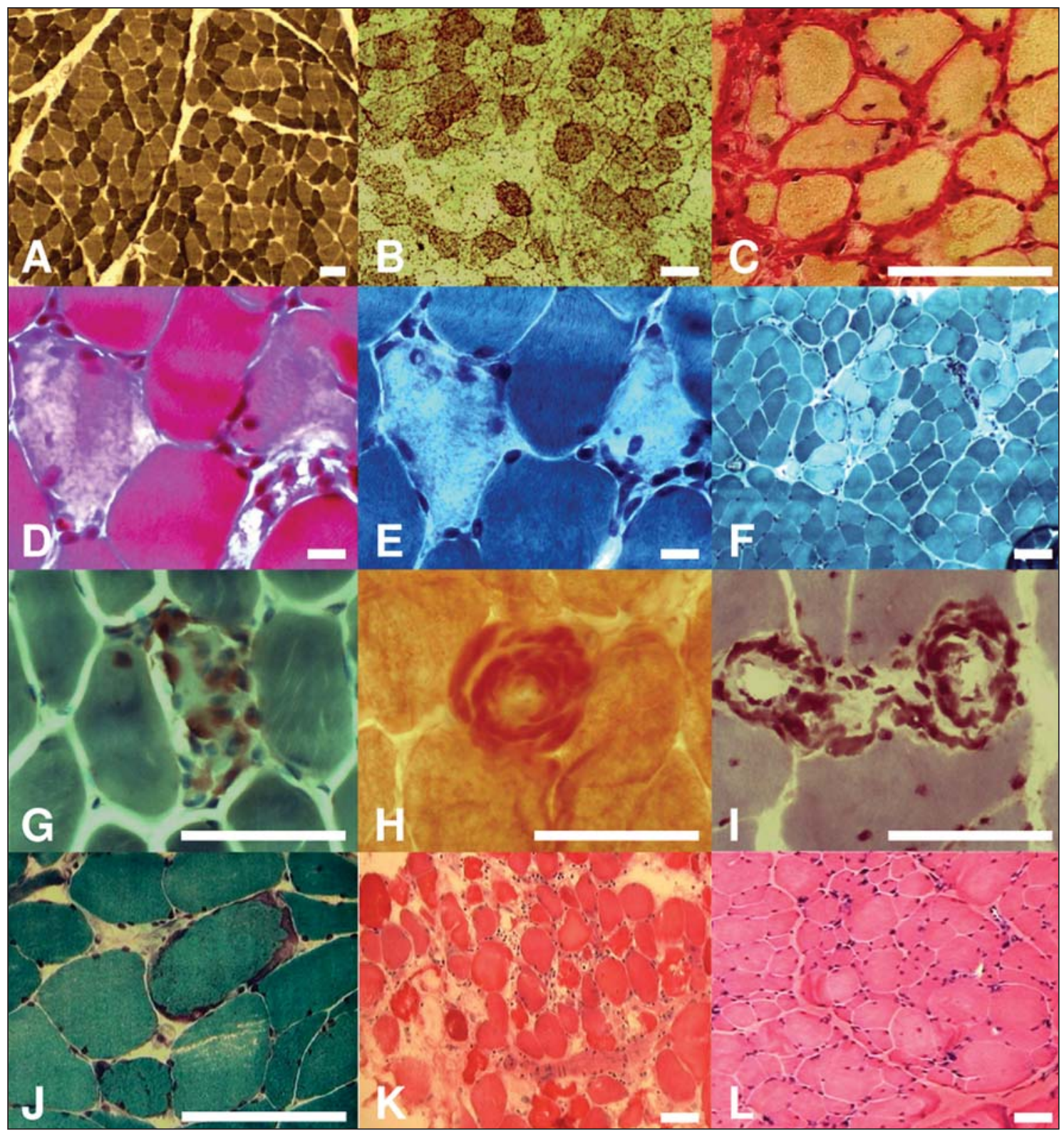

Fig 1. Histological and histochemical abnormalities in muscle biopsy: (A) selective atrophy of the type 2 fibers (case 29; ATPase $\mathrm{pH}$ 9.4); (B) type 1 fiber with lipid accumulation (case 23; Oil red O); (C) interstitial tissue increase (case 2; Siryus red); (D) fibers with simple necrosis (case 24; Hematoxylin-eosin); (E/F) fibers with simple necrosis (case 24; modified Gomori-trichrome); (G) phagocytes near or in necrotic fibers (case 24; Acid phosphatase); (H) amyloid deposis in vessel (case 30; Congo red); (I) metachromatic material in vessel and interstitial tissue (case 30; Cresyl violet); (J) ragged red fiber (case 32; modified Gomori-trichrome); (K) acute myopathy (case 16; Hematoxylin-eosin); and, (L) agglomerations of atrophic fibers (case 22; Hematoxylin-eosin). Bar: $50 \mu \mathrm{m}$.

cause muscle biopsy was not necessary for the TM diagnose.

Serum levels of muscle enzymes were normal in the majority of our patients, similar to the findings of the others studies ${ }^{1-3,9}$. Therefore, we believe that normal levels of CK or AL do not exclude the diagnosis of TM. Despite the fact that myopathic pattern is the most common abnormal finding in EMG, a normal EMG does not exclude the possibility of the TM either, since EMG studies were normal in $28 \%$ of our patients ${ }^{6}$. Other EMG abnormalities, namely denervation and mixed pattern did not preclude the diagnosis of TM on clinical grounds ${ }^{6}$.

The propoxyphene, neuroleptics (haloperidol), drug-induced hypokalemia and zidovudine were responsible for two cases of myopathy each. Intramuscular injection of propoxyphene induces local damage ${ }^{7,10,11}$. The myopathies caused by intramuscu- 
lar injections are due to repeated needle trauma as well as nonphysiologic acidity or alkalinity of the injected agent ${ }^{1,6,12}$. Neuroleptics can induce a myopathy with high levels of CK that is different of the neuroleptic malignant syndrome ${ }^{13}$. Serum CK levels may increase in as many as $10 \%$ of patients treated with atypical antipsychotic drugs ${ }^{14}$. Blockade of the serotonin 5-HT receptors on the sarcolemma is probably behind this type of $\mathrm{TM}^{14}$. Drug-induced hypokalemia may produce a reversible vacuolar myopathy, generally as a consequence of prolonged potassium serum levels below $2 \mathrm{mmol} / \mathrm{L}^{15}$. The exact mechanism which hypokalemia leads to muscle damage is unclear ${ }^{15}$. Propylthiouracil can also cause myopathy, although it is not well-established the role of hypokalemic or some other mechanism 1 .

The others cases of myopathy in our series were related to chloroquine, phenytoin, epsilon aminocaproic acid (EACA), organophosphate poisoning and azathioprine. Chloroquine can cause myopathy by increasing the activity of certain lysosomal enzymes in skeletal muscle, when used with daily dosages of $500 \mathrm{mg}$ for one year or longer ${ }^{16}$. Phenytoin may cause a hypersensitivity reaction characterized by fever, rash, lymphadenopathy, eosinophilia and inflammatory myopathy ${ }^{17}$. In our patient, the absence of such features in the muscle biopsy was probably due to the prolonged time of the progression of the disease (5 years). EACA is related with myonecrosis and myoglobinuria, as result of acquired carnitine deficien$\mathrm{cy}^{2,18}$. Organophosphates inhibit irreversibly an acetylcholinesterase enzyme resulting in accumulation of acetylcholine at the neuromuscular junction, thus leading to increased sodium and calcium entry into muscle cells and, ultimately, muscle damage ${ }^{1,19}$.

In one HIV positive patient the myopathy was related to zidovudine and the biopsy disclosed type 2 fiber atrophy, but this type of abnormalities also is common in the HIV patients ${ }^{20}$. This reversible, doserelated myopathy occurs in up to $20 \%$ of patients treated with zidovudine ${ }^{21}$. Mitochondrial myopathy by zidovudine was found in other HIV positive patient. The zidovudine can cause mitochondrial dysfunction, resulting from drug-induced inhibition of the mitochondrial DNA polymerase'.

One of our patients presented with myopathy following chronic use of azathioprine. It is known that some drugs used by patients with hematologic illnesses and those submitted to bone marrow transplant (BMT) are myotoxic in nature ${ }^{22}$. Jain reported a patient who presented with myopahty after BMT and chronic use of azathioprine ${ }^{22}$. Even though amyloid deposits in patients with silicone gel mammary prosthesis, as in case 30, are per se a rare finding, there is no previous description of myopathy due to amyloid deposit in such patients ${ }^{1-5,22,23}$.

The TM are a heterogeneous group of illnesses with different mechanisms of aggression to the muscular fiber. Neither an increase in the serum levels of $\mathrm{CK}$ and $\mathrm{AL}$, nor abnormal findings in EMG studies are obligatory for the diagnosis of TM. The findings of muscle biopsy, in the majority of cases, are nonspecific and the causal relation must be established based on a history of exposition to the myotoxic agent.

\section{REFERENCES}

1. Sieb JP, Gillessen T. Iatrogenic and toxic myopathies. Muscle \& Nerve 2003;27:142-156.

2. Sieb JP. Myopathies due to drugs, toxins, and nutritional deficiency. In Engel A, Franzini-Armstrong C (Eds). Myology: basic and clinical. New York: McGraw-Hill, 2004:1693-1712.

3. Wald JJ. The effects of toxins on muscle. Neurol Clin 2000;18:695-717.

4. Pascuzzi RM. Drugs and toxins associated with myopathies. Curr Opin Rheumatol 1998;10:511-520.

5. Walsh RJ, Amato AA. Toxic myopathies. Neurol Clin 2005;23:397-428.

6. Amato AA, Dumitru D. Acquired myopathies. In Dumitru D, Amato AA, Zwarts MJ (Eds). Electrodiagnostic medicine, second edition. Philadelphia: Hanley \& Belfus, 2002:1398-1416.

7. Werneck LC. The value of muscle biopsy in neurology: a study of 290 biopsies. Rev Bras Clin Ter 1981;10(Suppl):S2-S24.

8. Batchelor TT, Taylor LP, Thaler HT, Posner JB, DeAngelis LM. Steroid myopathy in cancer patients. Neurology 1997;48:1234-1238.

9. Hirano M, Ott BR, Raps EC, et al. Acute quadriplegic myopathy: a complication of treatment with steroids, nondepolarizing blocking agents, or both. Neurology 1992;42:2082-2087.

10. Fernandes-Sola J, Pedrol E, Masanes F, Casademont J, Grau JM, UrbanoMarquez A. Toxic myopathies: clinical, etiologic, and histologic study of 74 cases. Med Clin (Barc) 1993;100:721-724.

11. Werneck LC, Rachid A, Lozovey JCA. Propoxyphene myopathy: report of two cases with muscle histochemistry. Arq Neuropsiquiatr 1981;39: 68-79.

12. McCloskey JR, Chung MK. Quadriceps contracture as a result of multiple intramuscular injection. Am J Dis Child 1977;131:416-417.

13. Meltzer HY. Marked elevations of serum creatine kinase activity associated with antipsychotic drug treatment. Neuropsychopharmacology 1996;15:395-405.

14. Meltzer HY. Massive serum creatine kinase increases with atypical antipsychotic drugs: what is the mechanism and message? Psychopharmacology (Berl) 2000;150:349-350.

15. Comi G, Testa D, Comelio F, Comola M, Canal N. Potassium depletion myopathy: a clinical and morphological study of six cases. Muscle \& Nerve 1985;8:17-21.

16. Hughes JT, Esiri M, Oxbury JM, Whitty CW. Cloroquine myopathy. Q J Med 1971;40:85-93.

17. Tun NZ, Andermann F, Carpenter S, Karpati G. Antiepileptic drug myopathy. Neurology 1994;44:777-778.

18. Kane MJ, Silverman LR, Rand JH, Paciucci PA, Holland JF. Myonecrosis as a complication of the use of epsilon amino-caproic acid: a case report and review of the literature. Am J Med 1988;85:861-863.

19. Karalliedde L, Henry JA. Effects of organophosphates on skeletal muscle. Hum Exp Toxicol 1992;12:289-296.

20. Gabbai AA, Schmidt B, Castelo A, Oliveira ASB, Lima JGC. Muscle biopsy in AIDS and ARC: analysis of 50 patients. Muscle \& Nerve 1990; 13:541-544.

21. Dalakas MC, Illa I, Pezeshkpour GH, Laukaitis JP, Cohen B, Grif JL. Mitochondrial myopathy caused by long-term zidovudine therapy. N Engl J Med 1990;322:1098-1105.

22. Jain KK. Drug-induced myophathies. In Jain KK (Ed). Drug-induced neurological disorders. Toronto: Hogrefe \& Huber Publishers, 1996: 245-264.

23. Emekli U, Tumerdem B, Demiryont M. Rupture of a silicone gel mammary prosthesis and amyloidosis: a case report. Aesth Plast Surg 2002; 26:383-387. 